\title{
Pengaruh Hedonic Shopping Motives dan Promosi Penjualan Terhadap Impulse Buying Konsumen di Matahari Department Store Manado Town Square
}

\author{
Florensia Jovita Poluan \\ Johny R. E. Tampi \\ Danny D. S. Mukuan \\ Jurusan Ilmu Administrasi, Program Studi Administrasi Bisnis \\ Fakultas Ilmu Sosial dan Politik, Universitas Sam Ratulangi \\ florensiapoluan1997@gmail.com
}

\begin{abstract}
This study is to determine: partial influence of Hedonic Shopping Motives on Impulse Buying; Partial influence of Sales Promotion on Impulse Buying; simultaneous influence of Hedonic Shopping Motives and Sales Promotions on Impulse Buying. Type of Research is quantitative research. The sample that used in this research were 100 respondents who were consumers in Matahari Department Store Manado Town Square. The sampling technique using is probability sampling and the method that using is purposive sampling. Methods of data collection by questionnaire. Data analysis using is multiple linear regression. The results showed that: There is significant partial effect of Hedonic Shopping Motives on Impulse Buying. There is no partial effect of Sales Promotions on Impulse Buying. There is simultaneous effect between Hedonic Shopping Motives and Sales Promotions on Impulse Buying. Based on the result, it shows that Matahari Department Store Manado Town Square management can use the hedon motivation from their consumer to increase their sales. The company should increase their sales promotion to get consumer attention and to make compete ability in Indonesia retail business
\end{abstract}

\section{Keywords: Hedonic Shopping Motives, Sales Promotion, Impulse Buying}

\section{Pendahuluan}

Seiring dengan perkembangan zaman menyebabkan perubahan pada aspek-aspek kehidupan manusia, salah satunya aspek ekonomi. Hal ini dapat dilihat dari semakin banyaknya pusat perbelanjaan yang dibangun. Menurut data dari Asosiasi Pengelola Pusat Belanja Indonesia (APPBI) jumlah mall yang tersebar di wilayah Indonesia pada tahun 2014 berjumlah 250 unit dan pada tahun 2017 meningkat menjadi 312 unit. Seiring dengan perkembangan mall yang semakin pesat, memberikan peluang bagi pengusaha bisnis ritel untuk mengembangkan bisnis mereka. Pertumbuhan bisnis ritel tidak hanya disebabkan oleh kebutuhan dan keinginan masyarakat yang semakin kompleks namun juga disebabkan oleh perilaku masyarakat modern yang ingin segala sesuatunya serba cepat dan praktis. Hal ini dapat dilihat dari berubahnya pola kebiasaan manusia yang kini senang menghabiskan waktu di area mall untuk berekreasi dan berbelanja daripada 
berekreasi di alam terbuka. Berdasarkan fenomena tersebut, berbelanja tidak lagi merupakan aktivitas untuk memenuhi kebutuhan semata namun juga menjadi sarana untuk menghilangkan kepenatan dari aktivitas sehari-hari. Kegiatan berbelanja yang dilakukan masyarakat dipengaruhi oleh sifat hedonis yang muncul, yaitu kecenderungan membeli tidak berdasarkan kebutuhan. Motivasi berbelanja secara hedonis akan menyebabkan terjadinya pembelian yang tidak direncanakan atau impulse buying pada konsumen. Impulse buying yang sering dialami oleh para konsumen biasanya dimanfaatkan oleh perusahaan untuk meningkatkan volume penjualan yaitu dengan melakukan promosi penjualan. Promosi penjualan yang dilakukan perusahaan biasanya dapat berbentuk potongan harga pada produkproduk tertentu. Hal ini pula yang dilakukan oleh Perusahaan Matahari Department Store Manado Town Square. Promosi Penjualan yang dilakukan oleh Perusahaan Matahari adalah potongan harga, harga spesial, display yang menarik dan program bagi pengguna member card. Namun berdasarkan observasi dan pengalaman penulis, promosi penjualan yang mereka lakukan seringkali tidak sesuai dengan ekspektasi konsumen, misalnya: produk-produk yang mendapat potongan harga seringkali kondisinya sudah tidak sesuai atau rusak. Berdasarkan uraian latar belakang yang dikemukakan, saya ingin melakukan penelitian mengenai "Pengaruh Hedonic Shopping Motives dan
Promosi Penjualan terhadap Impulse Buying Konsumen di Matahari Department Store Manado Town Square"

\section{Pemasaran}

Pemasaran menurut Kotler (dalam Yusup, 2011) adalah "Suatu proses sosial dan manajerial dimana individu mendapatkan kebutuhan dan keinginan dengan menciptakan, menawarkan dan bertukar sesuatu yang bernilai, satu sama lain". Menurut Swastha (dalam Yusup, 2011) "Pemasaran adalah keseluruhan dan kegiatan usaha yang ditujukan untuk merencanakan, menentukan harga, mempromosikan, dan mendistribusikan barang dan jasa yang memuaskan kebutuhan baik kepada pembeli yang ada maupun kepada pembeli potensial. Secara lebih mudah, pengertian pemasarn adalah sistem keseluruhan dari kegiatan bisnis yang ditujukan untuk merencanakan, menentukan harga, mempromosikan, dan mendistribusikan produk atau jasa kepada pembeli serta berusaha memuaskan keinginan dan kebutuhan pembeli yang ada dan pembeli potensial.

\section{Hedonic Shopping Motives}

Hedonic berasal dari bahasa yunani yaitu berarti hedone yang berarti kesenangan atau kenikmatan. Lestari dan Oetomo (2014) mengatakan bahwa aspek hedonis berkaitan dengan emosional konsumen sehingga ketika berbelanja konsumen benar-benar merasakan sesuatu seperti senang, benci, marah, ataupun 
merasa bahwa berbelanja merupakan suatu petualangan.

Menurut Scarpi (dalam Suharyono, 2017), hedonic shopping menggambarkan nilai pengalaman berbelanja meliputi fantasi, sensor, rangsangan, kegembiraan, kesenangan, keingintahuan dan khayalan kegembiraan. Arnold dan Reynolds (dalam Suharyono, 2017) menyebutkan enam dimensi untuk mengukur tingkat hedonis seorang konsumen yang terdiri dari: Adventure shopping, Gratification shopping, Role shopping, Value shopping, Social shopping, dan Idea shopping.

\section{Promosi Penjualan}

$$
\text { Promosi penjualan }
$$

(Sales

Promotion) merupakan salah satu penentu keberhasilan suatu program pemasaran. Promosi penjualan pada hakekatnya adalah semua kegiatan yang dimaksudkan untuk menyampaikan atau mengkomunikasikan suatu produk atau jasa kepada pasar sasaran untuk segera melakukan suatu tindakan. Menurut Kotler (dalam Arifanti, 2011) sales promotion adalah "berbagai kumpulan alat-alat intensif, yang sebagian besar berjangka pendek, yang dirancang untuk merangsang pembelian produk atau jasa tertentu dengan lebih cepat dan lebih besar oleh konsumen atau pedagang". Promosi penjualan (Sales Promotion) memiliki sifat komunikatif, intensif dan undangan (Tjiptono, dalam Suharyono 2017). Dari berbagai sifat yang dimiliki promosi penjualan, terdapat beberapa jenis alat promosi penjualan untuk mengaplikasikan promosi penjualan. Alat promosi penjualan yang dapat dilakukan antara lain (Kotler, dalam Arifanti 2011) : Sampel, Kupon, Paket harga (potongan harga/diskon), Premium, Kontes, undangan dan permainan, Imbalan berlangganan, Garansi produk dan Pengujian gratis.

\section{Impulse Buying}

Impulse buying didefinisikan sebagai tindakan membeli yang sebelumnya tidak diakui secara sadar sebagai hasil dari suatu pertimbangan atau niat membeli yang terbentuk sebelum memasuki toko. Mowen and Minor (dalam Ratnasari, 2015) mendefinisikan pembelian tidak terencana sebagai desakan hati secara tiba-tiba dengan penuh kekuatan, bertahan dan tidak direncanakan untuk membeli secara langsung, tanpa memperhatikan akibatnya.. Menurut Utami (dalam, Kosyu 2014) pembelian impulsif adalah pembelian yang terjadi ketika konsumen melihat produk atau merk tertentu, kemudian konsumen menjadi tertarik untuk mendapatkannya, biasanya karena adanya ransangan yang menarik dari toko tersebut.

Menurut Rook dan Fisher (dalam, Kharis 2011) impulse buying atau pembelian impulsif memiliki beberapa karakteristik yaitu (1). Spontanitas, (2). Kekuatan, kompulasi dan intensitas, (3). Kegairahan dan stimulasi, (4). Ketidakpedulian akan akibat. 


\section{Metode Penelitian}

Dalam penelitian yang dilakukan pada konsumen Matahari Department Store Manado Town Square, penulis menggunakan metode penelitian kuantitatif. Populasi dalam penelitian ini adalah konsumen yang pernah melakukan pembelian secara tidak terencana di Matahari Department Store Manado Town Square yang tidak diketahui jumlah populasi pastinya. Untuk sampel yang digunakan yaitu sebanyak 100 orang. Teknik yang digunakan dalam menentukan sampel yaitu berdasarkan rumus dari Rao Purba (2006) dan diperoleh hasilnya yaitu sejumlah 100 orang. Teknik pengumpulan data yaitu dengan menggunakan kuesioner yang kemudian dinilai berdasarkan skala likert, dan model analisis yang digunakan adalah analisis regresi linear berganda

\section{Hasil Penelitian}

Hasil uji instrumen yang didapatkan dalam penelitian ini dengan menggunakan SPSS 25 for windows menyatakan bahwa semua kuesioner yang digunakan dalam penelitian ini adalah valid karena memiliki tingkat signifikansi sebesar 0,000 lebih kecil dari 0,005. Dari hasil uji reliabilitas yang dilakukan juga diperoleh nilai cronbach alpha untuk variabel Hedonic Shopping Motives yaitu sebesar 0,771, variabel Promosi Penjualan sebesar 0,833 dan variabel Impulse Buying sebesar 0,746, dimana semua nilai cronbach alpha lebih dari 0,6 sehingga dapat dikatakan reliable.
Pada penelitian ini, model analisis yang digunakan yaitu analisis regresi linear berganda. Hasil analisis regresi linear berganda diperoleh $Y=6,849+$ $0,438 X 1+0,151 X 2+$ e. Persamaan regresinya dapat dijelaskan sebagai berikut: (a). Nilai konstanta sebesar 6,849 menunjukkan bahwa jika tidak ada variabel independen ( Hedonic Shopping Motives dan Promosi Penjualan) maka Impulse buying berada ada angka 6,849. (b). Nilai Koefisien regresi X1 sebesar 0,438 artinya jika Hedonic Shopping Motives meningkat maka Impulse Buying konsumen juga akan meningkat, dengan asumsi variabel lain konstan. (c). Nilai koefisien regresi X2 sebesar 0,151 artinya jika Promosi Penjualan meningkat maka Impulse Buying konsumen juga akan meningkat, dengan asumsi variabel lain konstan.

Berdasarkan hasil analisis yang telah dilakukan dalam penelitian ini dapat diketahui bahwa variabel Hedonic Shopping Motives berpengaruh secara parsial terhadap Impulse buying, variabel Promosi penjualan tidak berpengaruh terhadap Impulse buying secara parsial dan Hedonic Shopping Motives dan Promosi Penjualan berpengaruh secara simultan terhadap Impulse buying. Hasil Uji Adjusted $\left(R^{2}\right)$ pada penelitian ini diperoleh nilai sebesar 0,289. Hal ini menunjukkan bahwa Hedonic Shopping Motives dan Promosi Penjualan memiliki kontribusi sebesar 28,9 \% dalam menciptakan Impulse Buying konsumen dan sisanya $71,1 \%$ dipengaruhi oleh kontribusi 
variabel-variabel yang tidak diteliti dalam penelitian ini.

\section{Pembahasan}

\section{Pengaruh Hedonic Shopping Motives terhadap Impulse Buying}

Nilai Koefisien regresi X1 sebesar 0,438 dan koefisien regresi bernilai positif menjelaskan bahwa apabila Hedonic Shopping Motives meningkat satu satuan maka Impulse Buying konsumen juga akan meningkat, sebesar 0,438 dengan asumsi variabel lain konstan. Maka dapat dikatakan bila seorang konsumen tidak merasakan motivasi berbelanja secara hedonis atau berbelanja yang tidak berdasarkan kebutuhan saat berbelanja di Matahari Department Store Manado Town Square maka akan memperkecil niat mereka untuk melakukan pembelian impulsif, maka keputusan untuk melakukan pembelian secara tidak terencana bisa lambat atau bahkan tidak ada. Begitu juga sebaliknya jika konsumen merasakan motivasi untuk berbelanja secara hedonis saat mereka berbelanja maka pada saat ada kesempatan, mereka akan secepatnya melakukan pembelian secara impulsif.

Ketika seseorang mempunyai nilai belanja hedonis yang tinggi maka hal tersebut dapat berpengaruh terhadap munculnya emosi positif yang meliputi rasa senang, bahagia, puas dan sejenisnya pada diri orang tersebut. Hasil penelitian ini juga mendukung penelitian yang dilakukan oleh Anggun Suci Kiswara Putri Suharyono (2017) yang menyatakan bahwa terdapat pengaruh yang positif dan signifikan dari Hedonic Shopping Motives terhadap Impulse buying. Indikatorindikator yang diukur dalam variabel Hedonic Shopping Motives adalah Adventure Shopping, Grattification Shopping, Role Shopping, Value Shoppping dan Idea Shopping. Bila dihubungkan dengan teori menurut Lestari dan Oetomo (2014) yang mengatakan bahwa aspek hedonis berkaitan dengan emosional konsumen sehingga ketika berbelanja konsumen benar-benar merasakan sesuatu seperti senang, benci dan marah. Hal ini menunjukkan bahwa ketika konsumen memiliki emosi yang positif, maka dapat meningkatkan keinginan untuk berbelanja secara hedonis yang nantinya berimbas pada pembelian secara tidak terencana.

\section{Pengaruh Promosi Penjualan terhadap Impulse Buying}

Nilai Koefisien regresi X1 sebesar 0,151 dan koefisien regresi bernilai positif menjelaskan bahwa apabila Hedonic Shopping Motives meningkat satu satuan maka Impulse Buying konsumen juga akan meningkat, sebesar 0,151 dengan asumsi variabel lain konstan. Hasil penelitian ini diketahui bahwa tidak terdapat hubungan yang signifikan antara Promosi Penjualan dan Impulse Buying. Hasil penelitian ini berbeda dari hasil penelitian yang dilakukan oleh Ria Arifanti (2011) yang menunjukkan bahwa Promosi Penjualan mempunyai pengaruh terhadap Impulse Buying. Indikator-Indikator yang 
digunakan dalam penelitian ini adalah Sampel, kupon, paket harga/diskon, premium, kontes/undian/permainan, imbalan berlangganan, garansi produk dan pengujian gratis. Perbedaan hasil penelitian ini dikarenakan oleh banyak faktor diantaranya, bedanya lokasi, populasi, sampel dan metode yang digunakan. Bila dihubungkan dengan teori dari Kotler (2005) yang menyatakan bahwa promosi penjualan adalah "berbagai kumpulan alat-alat intensif, yang sebagian besar berjangka pendek, yang dirancang untuk merangsang pembelian produk atau jasa tertentu dengan lebih cepat dan lebih besar oleh konsumen atau pedagang”. Promosi penjualan merupakan media untuk merangsang konsumen untuk melakukan pembelian atas suatu barang atau jasa tertentu, namun dalam prakteknya tidak semua promosi penjualan yang dilakukan perusahaan bisa membuat konsumen tertarik untuk melakukan pembelian. Konsumen sekarang cenderung kritis ketika melihat promosi yang dilakukan, misalnya potongan harga pada produk yang dia inginkan. Ada hal-hal yang menjadi pertimbangan konsumen sebelum melakukan pembelian misalnya mengenai kualitas barang yang mendapat potongan harga apakah sesuai dengan keinginan konsumen ataukah justru membuat konsumen tidak menginginkan produk itu lagi karena kualitas produknya buruk. Maka dapat dikatakan bahwa semakin menarik promosi penjualan yang dilakukan perusahaan belum tentu akan meningkatkan pembeliaan secara tidak terencana atau impulse buying.

\section{Pengaruh Hedonic Shopping Motives dan Promosi Penjualan Terhadap Impulse Buying}

Berdasarkan uji hipotesis (Uji t) yang telah dilakukan maka dapat dilihat bahwa Hedonic Shopping Motives dan Promosi Penjualan berpengaruh secara simultan terhadap Impulse Buying. Maka dapat dikatakan ketika seseorang mempunyai nilai belanja hedonis yang tinggi maka hal tersebut dapat berpengaruh terhadap munculnya emosi positif yang meliputi rasa senang, bahagia, puas dan sejenisnya pada diri orang tersebut. Dan ketika konsumen melihat suatu produk yang sedang diobral atau di sale maka akan menyebabkan terjadinya pengambilan keputusan yang salah satunya bersifat emosional. Pengambilan keputusan yang bersifat emosional dapat menyebabkan terjadinya pembelian secara tidak terencana. Jika dilihat dari koefisien regresi yang bersifat positif menunjukan bahwa semakin tinggi motivasi belanja hedonis seorang konsumen, dan semakin intens promosi penjualan yang dilakukan Matahari Department Store Manado Town Square maka akan menyebabkan konsumen melakukan pembelian secara tidak terencana.

Hasil penelitian ini juga mendukung penelitian yang dilakukan oleh Anggun Suci Kiswara Putri Suharyono (2017) yang menyatakan bahwa terdapat pengaruh yang positif dan signifikan dari Hedonic 
Shopping Motives dan promosi penjualan terhadap Impulse buying.

\section{Kesimpulan}

Berdasarkan hasil analisis dan pembahasan yang telah dilakukan dalam penelitian ini maka penulis dapat menarik kesimpulan:

Variabel Hedonic Shopping Motives berpengaruh positif dan signifikan terhadap Impulse Buying. Hal ini menunjukkan bahwa ketika seseorang mempunyai nilai belanja hedonis yang tinggi maka hal tersebut dapat berpengaruh terhadap munculnya emosi positif yang meliputi rasa senang, bahagia, puas dan sejenisnya pada diri orang tersebut. Hal ini yang kemudian menjadi penyebab terjadinya pembelian yang tidak direncanakan sebelumnya atau impulse buying.

Variabel bebas yang kedua adalah Promosi Penjualan (X2) tidak berpengaruh signifikan terhadap Impulse Buying. Hal ini menunjukkan bahwa semakin menarik promosi penjualan yang dilakukan pihak Matahari Department Store Manado Town Square belum tentu akan meningkatkan impulse buying konsumen, karena bisa saja promosi penjualan yang dilakukan tidak cukup baik atau tidak cukup menarik dibandingkan dengan kompetitor lainnya, sehingga konsumen cenderung mengabaikan aspek promosi penjualan ketika melakukan pembelian secara tidak terencana di Matahari Department Store Manado Town Square.
Variabel selanjutnya yaitu Hedonic Shopping Motives dan Promosi Penjualan secara bersama-sama atau simultan berpengaruh terhadap Impulse Buying. Hal ini dikarenakan munculnya emosi positif pada konsumen ketika sedang melakukan pembelian, ditambah dengan promosi penjualan yang dilakukan pihak Matahari Department Store, maka akan menyebabkan timbulnya pengambilan keputusan yang bersifat emosional. Pengambilan keputusan yang bersifat emosional dapat menyebabkan terjadinya pembelian secara tidak terencana. Jika dilihat dari koefisien regresi yang bersifat positif menunjukan bahwa semakin tinggi motivasi belanja hedonis seorang konsumen, dan semakin intens promosi penjualan yang dilakukan Matahari Department Store Manado Town Square maka akan menyebabkan konsumen melakukan pembelian secara tidak terencana

\section{Saran}

Pihak manajemen Matahari Department Store dapat memanfaatkan motivasi belanja secara hedonis yang dimiliki konsumen agar kedepannya perusahaan dapat meningkatkan penjualan. Motif belanja hedonis yang dapat menimbulkan pembelian impulsif adalah belanja untuk menghilangkan stress sehingga pihak perusahaan dapat menciptakan lingkungan yang menyenangkan bagi konsumen agar dapat menimbulkan emosi positif dalam 
berbelanja sehingga dapat meningkatkan pembelian impulsif.

Pihak Matahari Department Store Manado Town Square diharapkan agar dapat meningkatkan ketertarikan konsumen agar melakukan keputusan pembelian melalui promosi penjualan. Promosi penjualan yang dapat meningkatkan pembelian impulsif adalah pemberian diskon atau potongan harga, oleh karena itu pihak manajemen diharapkan dapat melakukan inovasi dengan melakukan promosi penjualan yang lebih menarik, untuk menarik perhatian konsumen yang senang berburu diskon, dan agar dapat merangsang konsumen untuk melakukan pembelian baik secara terencana maupun secara tidak terencana, agar nantinya dapat bersaing dengan perusahaan lainnya.

Bagi peneliti selanjutnya yang ingin meneliti atau melanjutkan penelitian ini disarankan untuk meneruskan atau mengembangkan penelitian ini dengan mencari faktor lain yang dapat menciptakan terjadinya perilaku impulse buying baik dari dalam diri konsumen maupun dari pemasar, misalnya store atmosphere, fashion involvement, shopping lifestyle, visual merchandising, bauran pemasaran dan variabel-variabel lainnya.

\section{Daftar Pustaka}

Arifianti, R. (2011). Pengaruh Promosi Penjualan terhadap Impulse Buying pada Hypermart di Kota Bandung. Universitas Padjajaran. Bandung
Kharis, I. F. (2011). Studi mengenai impulse buying dalam penjualan online di Lingkungan Universitas Diponegoro Semarang. Universitas Diponegoro. Semarang.

Kosyu, D. A, Kadarisma, H. dan Yusri, A. 2014. Pengaruh Hedonic Shopping Motives terhadap Shopping Lifestyle dan Impulse Buying. Jurnal Administrasi Bisnis. Vol 14 No. 21 -7 .

Lestari I. P, dan Oetomo, H. W. (2014). Pengaruh Hedonic Shopping Value Terhadap Impulse Buying Melalui Positive Emotion Customer Flashyshop. Jurnal Ilmu dan Riset Manajemen, Vol. 3, No. 7: 1-17

Ratnasari, V. A (2015). Pengaruh Store Atmosphere terhadap Hedonic Shopping Value dan Impulse Buying. Jurnal Administrsi Bisnis, Vol. 1, No. 1

Suharyono, Anggun Suci Kiswara Putri, (2017). Pengaruh Hedonic Shopping Motives dan Promosi Penjualan Terhadap Impulse Buying. Jurnal Administrasi Bisnis. 47(2): 145 153.

Yusup, M. (2011) Analisis Pengaruh Promosi, Harga, Kualitas Produk dan Layanna Purna Jual terhadap Keputusan Pembelian Motor Honda. Universitas Diponegoro. Semarang 